\title{
Does the Quality of Institutions Matter for Financial Inclusion? Cross Country Evidence
}

\author{
Peter W. Muriu ${ }^{1}$ \\ ${ }^{1}$ School of Economics, University of Nairobi, Kenya \\ Correspondence: Peter W. Muriu, School of Economics, University of Nairobi, Kenya. E-mail: \\ pmuriu@gmail.com
}

Received: April 13, 2021

Accepted: May 12, 2021

Online Published: June 5, 2021

doi:10.5539/ijef.v13n7p27

URL: https://doi.org/10.5539/ijef.v13n7p27

\begin{abstract}
Despite evidence on the importance of financial inclusion, little is known about the role of institutions in fostering inclusion partly because of data availability. Using annual data corresponding to 120 countries for the period 2004-2019, this study investigates country institutional characteristics associated with the ownership of deposit accounts. A standard regression model is estimated using fixed effects panel data techniques along with financial inclusion proxy and three measures of institutional quality. This paper provides the first empirical justification that financial inclusion is non-negligibly driven by the institutional context. Specifically, rule of law and quality of regulations are crucial in enhancing financial inclusiveness, more so in Africa where they have a stronger effect relative to other regions. Banks and depositors in Africa may be operating in an environment characterized by weak legal systems and excessive or challenging regulations. The evidence presented in this paper may therefore help with the sequencing of institutional reforms that could promote financial inclusion.
\end{abstract}

Keywords: cross-country, financial inclusion, political stability, rule of law, regulatory quality, panel data

\section{Introduction}

Financial inclusion is a major concern to policy makers globally (World Bank, 2016). Recent developments in the literature points to the critical role that access to finance plays in enhancing growth and reducing income inequality (Emara \& Said, 2021; Vaid et al., 2020; Anarfo et al., 2019). By smoothing out consumption, households can boost productive investment (Dupas \& Robinson, 2013). Micro enterprises can boost investment and expand scale (Chauvet \& Jacolin, 2017). Financial inclusion may also foster bank stability (Khan et al., 2021; Ahamed \& Mallick 2019) and boost future households' income (Kling et al., 2020). More importantly, financial inclusion enhances welfare by lowering poverty and inequality (Ofori-Abebrese et al., 2020; Neaime \& Gaysset, 2018).

The Alliance for Financial Inclusion (AFI) describes financial inclusion as access, use and quality of financial services. This definition has however been criticized particularly when conceptualized in developed countries since it does not differentiate between voluntary and involuntary exclusion (Salignac et al., 2016). Although account penetration depicts financial access, it does not reflect financial inclusion in its entirety. Due to data limitations and consistent with Kumar (2013) and Sarma (2008), this study adopts the narrow definition by focusing on the formal banking sector.

This paper investigates the influence of institutional quality on financial inclusion at the bank level. Specifically we investigate whether the influence of institutional quality on account penetration in Sub-Sahara Africa (SSA) differs significantly from the rest of the world. While most countries have recorded an improvement in account penetration, progress has been very uneven. Wang and Guan (2017) for instance, shows a geographical spatial aggregation distribution in which most SSA economies perform poorly on each of the financial inclusion measures compared to the developed nations. What explains this disparity?

The role of institutional differences in explaining account penetration is not yet well understood, partly because of data availability. Comparative data at the global level has not been forthcoming until 2004 with the launch of IMF's Financial Access Survey data. Similarly, comparable demand-side data, was not available prior to the first Global Findex database that was launched in 2011 (Demirgüç-Kunt et al., 2015). The Findex data however does not cater for variation across countries and changes over time for instance between 2011, 2014 and 2017. 
Whereas Findex data is only available every three years, IMF's Financial Access Survey data is available annually.

One important gap in the 'access to finance' strand of literature which has been less analysed, is the influence of institutions on financial inclusion. While existing literature has mainly focused on distrust of banks (Prymostka et al., 2020), the role of branch network expansion \& bank charges, (Allen et al., 2016), mobile account penetration (Beck et al., 2015; William \& Suri, 2014), culture (Lu et al., 2021), gender (Girón et al., 2021; Khmous \& Besim, 2020; Aterido et al., 2013), population density (Cámara \& Tuesta, 2015) income, education, industrialization, employment (Dar \& Ahmed, 2020; Mhlanga et al., 2020), financial literacy (Grohmann \& Menkhoff, 2018), financial innovation (Beck et al., 2015), regulation (Beck et al., 2010) as the drivers of financial inclusion, this study contributes to the existing literature by examining the role of institutional quality on financial inclusion across developed and developing countries.

This study builds on previous research and new database to understand two fundamental questions related to financial inclusion: does institutional quality explain variation in account penetration? Second, does our estimation model predict that institutional constraints have disproportionate influence on SSA region? These questions illuminate an important channel through which institutions could affect financial inclusion but which remains relatively under-examined. Due to the theoretical gap on institutions-financial inclusion nexus, this study is anchored on financial development theory.

This paper makes at least three main contributions to an emerging literature on financial inclusion. First, it is timely in view of the critical role that institutions play in fostering access to financial services. Second, although there is consensus that institutional differences are fundamental in explaining national development paths, the role of financial inclusion is still fairly new. Third, if the study establishes that weak institutions curtail financial inclusion, then measures that could strengthen institutions to foster sustainable provision of financial services should be adopted.

This study is structured as follows. The next section offers stylized facts on account penetration as well as the quality of institutions over time, relying on Financial Access Survey and World Governance Indicators (WGI) data. A brief review of the literature is presented in section 3. Section 4 presents the econometric approach and data employed. Section 5 discusses the baseline regression results as well as the interaction effects. Section 6 concludes.

\section{Stylized Facts}

This section documents stylized facts on the main variables of interest, i.e. growth of account ownership and institutional indicators over time. This preview motivates the choices of the variables that we make for regression analysis.

\subsection{Financial Inclusion}

Figure 1 shows global growth in deposit account penetration. With the exception of SSA, the rest of the regions have seen quite some variation over time. It is worth noting, that, SSA lags behind which is consistent with Ofori-Abebrese et al. (2020) and Wang and Guan (2017). An interesting stylized fact to note is the significant drop in account penetration across countries witnessed from 2007 to 2009 due to the global financial crisis. This drop was more pronounced among the high income regions of Europe and Central Asia which had recorded high growth prior to the crisis.

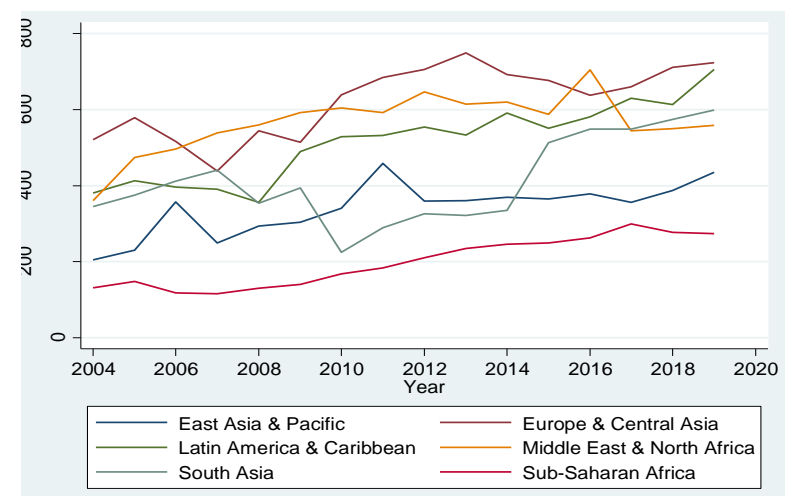

Figure 1. Deposit account penetration over time and across regions 


\subsection{Institutional Quality}

Consistent with account penetration, Figure 2 shows that Central Asia and Europe region has over time reported high levels of observance of rule of law. Notably also, South Asia has been on decline since 2007. The region has over time reported the lowest scores which according to the WJP Rule of Law Index there is little acceptance within the private sector of the jurisdiction of the courts in civil and commercial matters. SSA performs poorly as well which is consistent with Anayiotos and Toroyan (2009) who shows that financial sector across SSA economies operate within weak institutional environment. Of the 35 SSA nations reported in the 2019 Global Competitiveness Index, 26 score below 4, in terms of institutions index which covers property rights protection, judicial independence, burden of government regulation, placing them among the worst 51 countries. Additionally, 39 out of the 48 nations reported in the 2021 Economic Freedom Index (Heritage Foundation) are considered either "repressed" or "mostly unfree".

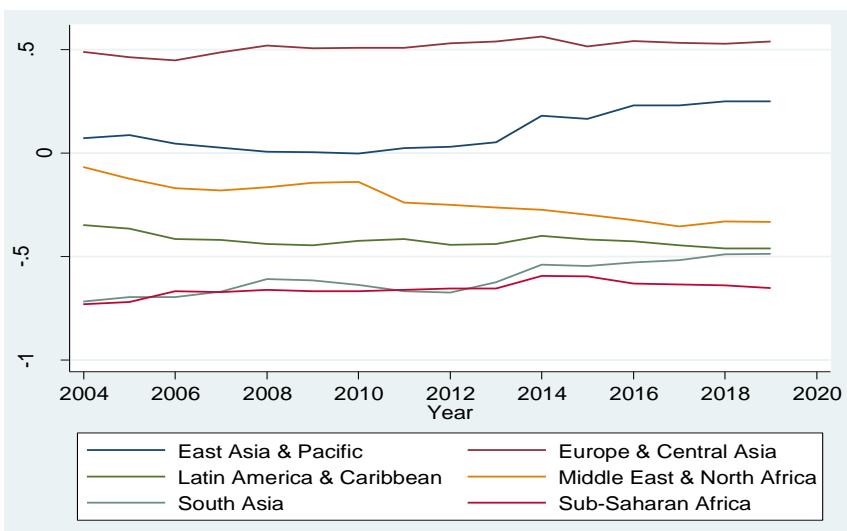

Figure 2. Rule of Law

Source: WGI (2021), and calculation by author.

The trend is almost replicated on the regulatory quality. While not surprising, Central Asia and Europe has maintained the lead in terms of regulatory quality, SSA has lagged behind. Johnson and Williams, (2016), observes that for financial inclusion to succeed in Pakistan, the Central Bank had to bypass the official regulations.

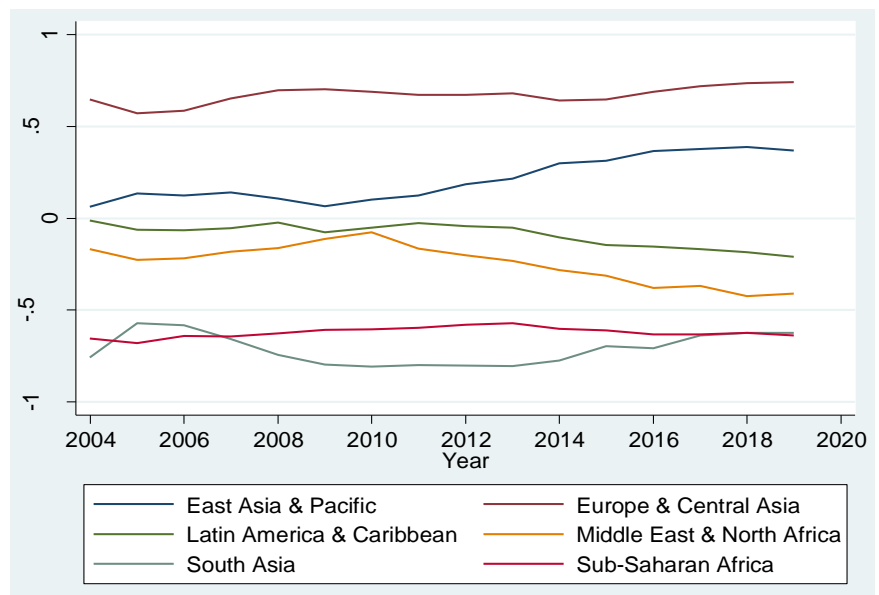

Figure 3. Regulatory quality

Source: WGI (2021), and calculation by author.

The uncertainty associated with political instability adversely affects financial inclusion by lowering the growth of financial innovations and banking infrastructure. Figure 4 shows that Europe and Central Asia region has relatively been stable over time. As from the year 2010, Middle East and the North Africa region has been politically unstable due to the Arab Spring revolution and the ongoing war in Syria and Yemen.

Sub-Sahara Africa has also been on a downward trend since 2012 perhaps due to simmering conflicts, particularly in the fragile states. Political upheavals and conflicts in Madagascar, Mali, DRC, Central African 
Republic, Togo, Guinea, Burundi, South Sudan, Guinea-Bissau, Burkina Faso and politically instigated labour unrest in South Africa suggest that political instability due to elections remains unabated. Security risks have also been manifested through Boko Haram insurgencies in some countries such as Chad, Cameroon, Nigeria, Niger and terrorist threats in Kenya.

Different political institutions and power leads to different distribution of resources. It may be the case that some SSA countries use political power in a manner that is likely to influence the cost of financial intermediation (Acemoglu \& Robinson, 2008). Although a vast majority of these countries describe themselves as democracies and conduct elections at fairly regular intervals, their commitment to political pluralism, accountability, genuine electoral competition and civil liberties are wanting. For some countries e.g. Ethiopia, Uganda, Rwanda, Burundi, Sudan and Angola democracy has little meaning beyond the ritual holding of elections where political space is severely constrained. These stylized facts therefore demonstrate an intertwined relationship between access to finance and measures of institutional quality.

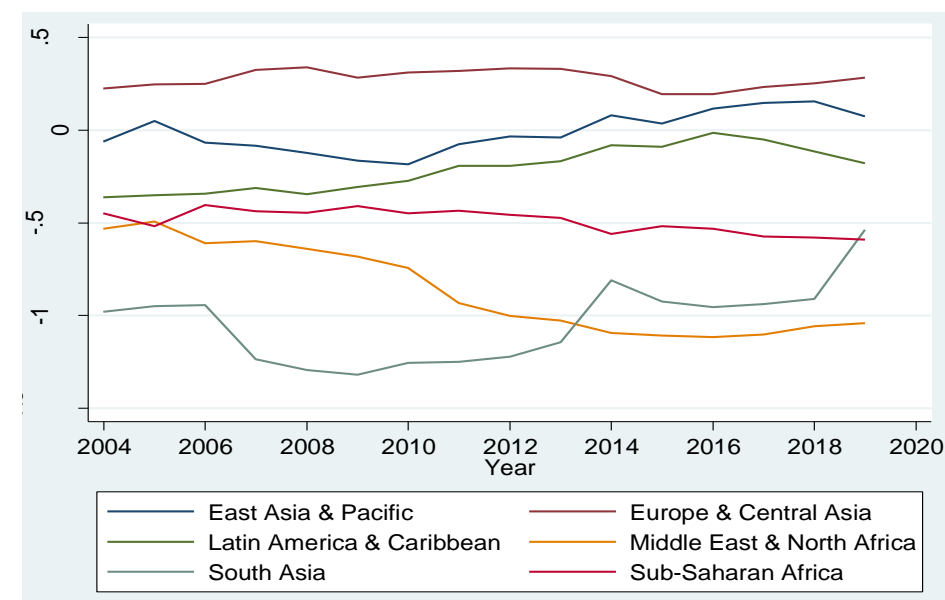

Figure 4. Political stability and absence of violence/terrorism

Source: WGI (2021), and calculation by author.

\section{Related Literature}

Institutions are constraints that determine social, economic and political interaction (North, 1990). From this perspective, the institutional quality may affect financial inclusion when financial market channels resources to finance investments. Good institutions may therefore enhance financial inclusion by overcoming transaction and information cost. While applying autoregressive distributed lag model and quarterly data, Onyinye et al. (2019) investigate the role of institutions on access to bank accounts in Nigeria. They find that quality of institutions significantly impacts on financial inclusion in the short and long run periods. Using two-stage least-squares and generalized method of moments (GMM) estimation techniques, Minhaj et al. (2020) finds that quality of institutions significantly enhances financial inclusion. This finding supports Saydaliyev et al. (2020), who also find financial inclusion to be associated with better institutional quality.

This study is related to a growing literature on institutions and financial development. Özlem et al., (2018) examine the relationships between institutional quality and financial development for the year 2012 and finds a significant positive relationship. Fergusson (2006), Beck and Levine (2008) provide a comprehensive review of literature on the role of legal institutions on financial development. More specifically, legal institutions may enhance financial sector development (Huang, 2010). Financial constraints are more widespread in countries where the legal system is weak (Love, 2003).

For the case of Sub-Sahara Africa, Alter and Yontcheva (2015) document a positive and significant relationship between the rule of law and financial development gap for all SSA while government effectiveness and property rights applies to franc zone countries. Along the same vein, Ahokpossi et al. (2013) shows that the poor development of the West African Economic and Monetary Union financial sectors is attributed to the variations in the rule of law. Based on cross-country studies, Acemouglu and Johnson (2005) conclude that secure property rights and contract enforcement prevents government expropriation thus facilitating a robust financial market.

Perhaps surprisingly are the conflicting findings on the relationships between financial development and legal 
origin. Beck et al., (2003) provide evidence which suggests that law and finance hypothesis has some merit in demonstrating cross-country variations in financial development. Common law legal systems provide greater flexibility by adapting more easily to dynamic financial architecture. This has been the hindrance to the growth of use of mobile money system in Latin America. On the contrary civil law systems may boost financial system once laws are adopted as demonstrated by the Mexico correspondent banking (BFA, 2009).

Closely related to the rule of law is regulatory impediment. A growing literature shows that banking regulations in some countries curtail competition (Mostak et al., 2021)). Constraints to banking activities and entry raise the cost of financial intermediation (Anginer et al., 2018). Central Banks may for instance control banks' branch expansion (Beck et al., 2010). Banks may also face activity restrictions with implications on efficiency and economies of scope. Whereas Indonesia, Japan and many SSA countries impose severe restrictions on bank activity, United Kingdom, Austria, Switzerland and Germany impose minimal restrictions (Chen et al., 2020). Moreover, defaults on loan are a major hindrance to bank lending when regulation quality is poor (Andrianova et al., 2015).

Regulation may also constrain the development of mobile money penetration by limiting the operator's freedom in structuring the business model and service provision. Globally, Kenya has the highest mobile money penetration at almost $60 \%$ of the population (Patnam \& Yao, 2020). The growth of MPESA has largely been attributed to relaxed regulation where the Central Bank allowed Safaricom to operate M-PESA outside the provisions of the banking law (Ouma et al., 2017; Mas \& Radcliffe, 2011). Financial inclusion progress in Pakistan is partly attributed to the efforts of Central Bank which bypassed regulations and established a financial inclusion unit (Johnson \& Williams, 2016).

Political instability raises foreign investors' risk perception, which inceases the cost of capital (Liu \& Zhong, 2017). Using monthly data, Aaberge et al. (2017) shows that political uncertainty leads to significant increase in household savings in China. Demeatrides and Fielding (2012) finds political instability as a constraint to financial development in eight West African economies. Roe and Siegel (2011) finds a positive relationship between political stability and financial development. Evidence on the influence of political stability on financial inclusion in SSA has been documented by Anayiotos and Toroyan (2009) and for the case of Asian countries by Gani and Ngassam (2008).

These findings suggest that institutional reforms such as political stability, the quality of the regulatory environment, rule of law \& legal origin are important drivers of financial development. A major drawback with these studies is that they rely on variables such as liquid liabilities of banks, private-sector credit and the stock market capitalization as proxies for financial deepening. Moreover, what holds true for financial development may not necessarily hold for financial inclusion.

There are few exceptions. Using Global Findex data, Eldomiaty et al., (2020) analyse the role of institutions on access to finance at the global level. They establish that control of corruption, government effectiveness, political stability and voice \& accountability influence financial inclusion. Their study suffers from methodological weaknesses. First, it has used all the six institutional variables in a single equation which is not plausible since by default the variables are highly correlated (Kaufmann et al., 2009). Second, the study does not provide theoretical justification as to how all the six institutional variables would affect financial inclusion. Third, the study has used fixed effects estimation which is not appropriate when using time invariant regional dummies. Zulkhibri and Ghazal (2017) investigate the relationship between institutions and financial inclusion in Muslim and developing countries. Their findings suggest that governance positively influences account ownership. Allen et al. (2016) establish that political stability and rule of law enhances financial inclusion. All these studies however have one limitation. They are based on simple cross-sectional regressions that do not allow for any causal interpretation.

There are also studies that have investigated determinants of financial inclusion. Using 2017 Global Findex database, mean difference tests and binary probit regressions models, Martinez et al., (2020) examine the key determinants of access to finance in Latin America. Their study findings reveal that household income, education and age positively affect financial inclusion. This finding lends credence to Khmous and Besim (2020) who arrives at the same conclusion for MENA countries.

The role of economic growth in enhancing financial inclusion has been analysed by Gebrehiwot et al, (2019) using GMM estimator across 27 Africa countries. They establish that per capita income influences access to finance positively. Using annual data for the period 2010 to 2017, GMM and Hansen's estimation techniques to uncover factors that influence financial inclusion, Nsiah et al., (2021), concludes that credit to private sector enhances financial inclusion. A growing body of research suggests that financial technology (FinTech) boosts financial inclusion (Panos \& Wilson, 2020) and therefore FinTech is a key enabler of financial inclusion (Demir et al., 2020). 
Driven by financial innovations, mobile banking has significantly reduced the costs of banking, fostered risk-sharing more effectively and therefore accelerated financial inclusion (Aron, 2018).

\section{Data and Methodology}

\subsection{Model Specification}

The empirical specification seeks to explain the determinants of financial inclusion by examining the influence of institutions. For the purpose of estimation, a general linear model is specified as follows:

$$
Y_{i t}=\alpha_{0}+\beta_{1} I N S_{i t}+\beta_{2} X_{i t}+\mu_{i}+\varepsilon_{i t}
$$

Where $Y_{i t}$ denotes financial inclusion. INS is institutional quality, $\alpha_{0}$ is the intercept and $X_{i t}$ is a matrix of control variables that includes macroeconomic, country-specific socio-economic indicators, the subscripts $i$ and $t$ captures countries and time respectively. $\mu_{i}$ is the unobservable country-specific and $\varepsilon_{i t}$ is the stochastic disturbance error-term following normal distribution with mean 0 and variance $\sigma^{2}$.

\subsection{Econometric Approach}

We estimate equation (1) using unbalanced panel data estimation technique. This is because for some years data is not available. Panel data controls for heterogeneity across cross-sections due to their inherent characteristics' variations. Additionally, it discounts for time effects, which may occur due to changes in policy and other socio macroeconomic environment. Panel data also controls for country-specific effects which cross-section estimation does not take into account. It also overcomes endogeneity of the regressors (Baltagi, 2021). Moreover, panel data circumvents errors in model specification. To arrive at the most appropriate model between a Fixed and Random Effect models we perform Hausman test. As per the null hypothesis, the preferred model is the random effects. In the event that the p-value is small (less than 0.05), we reject the null hypothesis.

\subsection{Measurement of Variables}

Existing literature offers various measures of financial inclusion at the bank level. Studies using Global Findex database consider account ownership, savings, bank charges and frequency of use (Mohammed et al., 2017; Wale \& Makina, 2017; Zinsa \& Weill, 2016). There are also studies that have used index of financial inclusion such as Nguyen (2021), Nizam et al. (2020), Amidžić et al. (2014), Sarma (2008). A major shortcoming of indices is that there is no convergence on the agreed indicators and the availability of reliable data. In this study, we use depositors with commercial banks per 1,000 adults. While this variable is appropriate measure of inclusive finance in the mainstream banking sector, it is nevertheless not a broad measure of inclusion since it excludes mobile money and microfinance institutions.

Literature provides diverse measures of institutional quality. These include Worldwide Governance Indicators (WGI), Index of Economic Freedom, Gallup World Poll (GWP), Doing Business Indicators and ICRG disaggregated business risk indicators. This study utilized WGI available at www.govindicators.org. Kaufmann et al. (2009) has constructed six different dimensions of governance. Not all governance indicators are relevant on financial inclusion. We select three institutional dimensions which are closely related to inclusive finance and which are clearly established in the existing literature. They are measured as follows;

Rule of law (RL) captures the likelihood of violence and crime, contract enforcement including whether property rights are upheld. Political stability and absence of violence/terrorism (PS) captures politically motivated violence, terrorism and the probability of coup detat. Regulatory quality (RQ) captures the quality of regulations that provide an enabling environment for the development of private sector.

WGI, ranges from -2.5 to 2.5 , where higher values reflects better outcomes. The institutional indicators are clustered in a manner that allows inference on whether some dimensions matter for financial inclusion. Many cross-country studies that have used WGI find the data sufficiently informative to the extent that they report statistically significant differences in the estimated results. This demonstrates that institutional quality may vary even over short period of time. Their wide coverage and usage allows for comparison with the existing literature. Previous studies that have used WGI include Eldomiaty et al., (2020), Zulkhibri and Ghazal (2017), Alter and Yontcheva (2015). Table 1 presents definition and measurement of the variables while Table 2 shows the predicted effects a priori based on theory and empirical literature. 
Table 1. Definition and measurement of variables

\begin{tabular}{|c|c|c|c|c|}
\hline Variable in the empirical model & Empirical counterparts & $\begin{array}{l}\text { Observed } \\
\text { Counterpart }\end{array}$ & $\begin{array}{l}\text { Availability } \\
\text { (sample period) }\end{array}$ & $\begin{array}{l}\text { Source of } \\
\text { data }\end{array}$ \\
\hline \multicolumn{5}{|l|}{ Endogenous variable } \\
\hline $\begin{array}{l}\text { DEP } \\
\text { Measured as the number of } \\
\text { depositors with commercial banks } \\
\text { per } 1,000 \text { adults }\end{array}$ & $\begin{array}{l}\text { CAPDEPO } \\
=\text { number of depositors with accounts/ pop }\end{array}$ & $\begin{array}{l}\text { Deposit } \\
\text { accounts } \\
\text { ownership }\end{array}$ & $\begin{array}{l}\text { 2004-2019, } \\
\text { annual data }\end{array}$ & $\begin{array}{l}\text { Financial } \\
\text { Access } \\
\text { Survey, } \\
\text { IMF }\end{array}$ \\
\hline \multicolumn{5}{|l|}{ Exogenous variables } \\
\hline $\begin{array}{l}\text { PS } \\
\text { Political Stability }\end{array}$ & $\begin{array}{l}\text { PS=the likelihood of violent government } \\
\text { takeover }\end{array}$ & $\begin{array}{l}\text { Political } \\
\text { stability }\end{array}$ & $\begin{array}{l}\text { 2004-2019, } \\
\text { annual data }\end{array}$ & WGI \\
\hline $\begin{array}{l}\text { RQ } \\
\text { Regulatory Quality }\end{array}$ & $\begin{array}{l}\mathrm{RQ}=\text { a proxy for quality of regulations that } \\
\text { provide an enabling environment for the } \\
\text { development of private sector }\end{array}$ & Regulation & $\begin{array}{l}\text { 2004-2019, } \\
\text { annual data }\end{array}$ & WGI \\
\hline $\begin{array}{l}\text { RL } \\
\text { Rule of Law }\end{array}$ & $\begin{array}{l}\mathrm{RL}=\text { captures the likelihood of crime and } \\
\text { violence, quality of contract enforcement } \\
\text { including whether property rights are upheld }\end{array}$ & $\begin{array}{l}\text { Commercial } \\
\text { justice }\end{array}$ & $\begin{array}{l}\text { 2004-2019, } \\
\text { annual data }\end{array}$ & WGI \\
\hline \multicolumn{5}{|l|}{ Control variables } \\
\hline $\begin{array}{l}\text { GDP } \\
\text { Measured as GDP per capita } \\
\text { (constant } 2010 \text { US\$) }\end{array}$ & $\begin{array}{l}\text { INCOME } \\
=\mathrm{GDP} / \mathrm{POP}\end{array}$ & $\begin{array}{l}\text { Per capita } \\
\text { GDP }\end{array}$ & $\begin{array}{l}\text { 2004-2019, } \\
\text { annual data }\end{array}$ & WDI \\
\hline $\begin{array}{l}\text { URBAN } \\
\text { Measured as urban population as } \\
\text { a } \% \text { of total population }\end{array}$ & $\begin{array}{l}\text { URBANPOP } \\
=\text { urban population/total population }\end{array}$ & $\begin{array}{l}\text { Urban } \\
\text { population }\end{array}$ & $\begin{array}{l}\text { 2004-2019, } \\
\text { annual data }\end{array}$ & WDI \\
\hline $\begin{array}{l}\text { UNEMPLOY } \\
\text { Measured as Unemployed } \\
\text { individulas /total labour force }\end{array}$ & $\begin{array}{l}\text { UNEMPRATIO } \\
=\text { Unemployed /total labour force }\end{array}$ & $\begin{array}{l}\text { Employment } \\
\text { status }\end{array}$ & $\begin{array}{l}\text { 2004-2019, } \\
\text { annual data }\end{array}$ & WDI \\
\hline $\begin{array}{l}\text { MOBILE } \\
\text { Measured as mobile cellular } \\
\text { subscriptions (per } 100 \text { people) }\end{array}$ & $\begin{array}{l}\text { MOBRATIO } \\
=\text { Phone subscription/ per } 100 \text { people }\end{array}$ & $\begin{array}{l}\text { Mobile phone } \\
\text { subscriptions }\end{array}$ & $\begin{array}{l}\text { 2004-2019, } \\
\text { annual data }\end{array}$ & WDI \\
\hline $\begin{array}{l}\text { INTERNET } \\
\text { Measured as fixed broadband } \\
\text { subscriptions per } 100 \text { people }\end{array}$ & $\begin{array}{l}\text { INTERNET=internet subscription/ per } 100 \\
\text { people }\end{array}$ & $\begin{array}{l}\text { Internet } \\
\text { utilization }\end{array}$ & $\begin{array}{l}\text { 2004-2019, } \\
\text { annual data }\end{array}$ & WDI \\
\hline
\end{tabular}

Table 2. Expected sign of each explanatory variable on the dependent variable

\begin{tabular}{llll}
\hline Variable & \multicolumn{2}{l}{$\begin{array}{l}\text { Endogenous variable } \\
\text { Depositors with commercial banks per }\end{array}$} & \\
\hline $\begin{array}{l}\text { Explanatory variable /determinant } \\
\text { Institutional environment }\end{array}$ & Expected sign & Sign predicted by theory & Sign from previous empirical studies \\
Political Stability & Positive & Positive & Positive \\
Regulatory Quality & Positive & Positive & Positive \\
Rule of Law & Positive & Positive & Positive \\
Control variables & & & Indeterminate \\
GDP & Positive & Indeterminate & Positive \\
Urban population & Positive & Positive & Negative \\
Unemployment & Negative & Negative & Positive \\
Mobile cellular & Positive & Positive & Positive \\
Fixed broadband & Positive & Positive & \\
\hline
\end{tabular}

\subsection{Data}

This study used annual account penetration data from International Monetary Fund's annual Financial Access Survey (2021) and institutional data from WGI. Financial Access Survey provides supply-side data covering 189 jurisdictions, with more than 100 series and historical data from 2004. The entire data set covers the period 2004 to 2019. Control data at the country level were obtained from World Development Indicators. Not all variables for the study period are available and therefore the panel is unbalanced. The country dimension covers 120 
countries whose data for most of the financial inclusion and institutional variables are available spanning across six regions and distributed as East Asia \& Pacific (9), Europe \& Central Asia (32), Latin America \& Caribbean (21), Middle East \& North Africa (12), South Asia (7) and Sub-Saharan Africa (39). The regional distribution is as mapped by World Bank.

\section{Endogenous variables}

Previous studies have used a variant of endogenous variables to capture financial inclusion. Kumar (2013) and Sarma (2008) for instance have used per capita bank accounts. The IMF data has two proxies that capture account penetration; depositors with banks per 1,000 adults and deposit accounts with banks per 1,000 adults. It is however worth noting that the latter may bias the account ownership since some clients may possess several accounts, even within a single bank. To circumvent this problem, we use depositors with banks per 1,000 adults as the proxy for account penetration. The advantages of focusing on account ownership are as follows; first, the indicator is comparable across economies. Second, this circumvents aggregation problem which is common with indices.

\section{Exogenous variables}

The institutional quality data are those assembled by Kaufmann et al., (2009). The study also considered a set of country-level characteristics that theoretical and empirical literature has identified as potential control variables that may explain financial inclusion. The ratio of urban population to total population is expected to positively influence inclusive finance since there are more bank establishments in urban centres relative to rural areas.

Per capita income has been included to capture the role of economic performance on account penetration. Higher income should translate to more financial inclusion. The ratio of unemployed individuals to the total labour force, represents employment status. Countries with higher unemployment may be more excluded financially. We therefore expect unemployment rate to affect financial inclusion negatively.

To account for technological advances, the study considers two indicators that capture the role of technological innovations. These are internet usage and mobile phone subscriptions; measured as fixed broadband subscriptions per 100 people and mobile cellular subscriptions respectively. We expect these indicators to enhance financial inclusion.

\section{Empirical Findings and Discussions}

Table 3 shows the summary statistics. The minimum and maximum values for the mean and standard deviation for each variable suggest wide range/outliers. We therefore used robust regression methods. The descriptive statistics further reveals a clear disparity among countries. On average there are 335 depositors per 1,000 adults which translate to about 34 percent across 120 countries under study.

Table 3. Descriptive statistics

\begin{tabular}{lcccccc}
\hline Variable & Notation & Obs & Mean & Standard Deviation & Minimum & Maximum \\
\hline Depositors with commercial banks & DEP & 1,490 & 335.4 & 294.0 & 0.409 & 999.9 \\
Log GDP per capita & GDP & 1,973 & 8.37 & 1.512 & 5.319 & 11.48 \\
Population density & POP & 1,979 & 242.7 & 873.4 & 1.609 & 7804 \\
Urban population & URB & 1,979 & 57.30 & 22.79 & 8.441 & 100 \\
Unemployment & UNEM & 1,938 & 8.89 & 6.55 & 0.100 & 37.58 \\
Mobile cellular subscriptions & MOB & 1,975 & 79.71 & 46.84 & 0.187 & 236.8 \\
Fixed broadband subscriptions & INTERN & 1,845 & 7.48 & 10.27 & 0 & 46.10 \\
Political Stability & PS & 1,976 & -0.266 & 0.941 & -2.811 & 1.611 \\
Regulatory Quality & RQ & 1,977 & -0.0712 & 0.910 & -2.351 & 2.271 \\
Rule of Law & RL & 1,978 & -0.195 & 0.928 & -1.994 & 2.134 \\
\hline
\end{tabular}

When summary statistics are further clustered into regions, some interesting disparities emerge. Table 4 shows that while most countries have recorded an improvement in account penetration, progress has been very uneven. Europe and Central Asia has on average reported higher account penetration compared to other regions. Adults in Europe and Central Asia are about three times more likely to own a deposit account compared to those in Sub-Sahara Africa. It is the same narrative on the quality of institutions. SSA economies perform worse than the global average in terms of political stability, regulatory quality and rule of law which is consistent with low levels of financial inclusion. 
Table 4. Financial inclusion and institutional indicators: Mean values 2004-2019

\begin{tabular}{lcccc}
\hline \multicolumn{2}{c}{ Depositors } & Institutional quality indicators & & PS \\
\hline Region & & RL & RQ & -0.51 \\
SSA & 224 & -0.69 & -0.63 & 0.29 \\
ECA & 710 & 0.50 & 0.69 & -0.49 \\
MENA & 590 & -0.21 & -0.20 & -0.06 \\
EAP & 351 & 0.04 & 0.17 & -1.17 \\
SA & 454 & -0.61 & -0.61 & -0.28 \\
LAC & 608 & -0.40 & -0.06 & \\
\hline
\end{tabular}

Source: Financial Access Survey (2021), World Governance Indicators (2021) and computation by author.

$\mathrm{RL}=$ Rule of law; RQ=Regulatory quality; PS=Political stability.

Table 5 reports the correlations matrix. The institutional variables show very high bivariate correlations which is consistent with Kaufmann et al. (2009). Causal impact from one institutional variable to another may explain the high correlations. For example, political instability hinders rule of law (Roe \& Siegel, 2011). Electoral competition may affect regulatory quality (Alence 2004). Thus we fitted a series of regressions due to multicollinearity between these institutional indicators.

Table 5. Correlations matrix

\begin{tabular}{|c|c|c|c|c|c|c|c|c|c|c|}
\hline & DEP & GDP & POP & URB & UNEM & MOB & INTER & PS & RQ & RL \\
\hline DEP & 1 & & & & & & & & & \\
\hline GDP & 0.6081 & 1 & & & & & & & & \\
\hline POP & -0.0184 & 0.1771 & 1 & & & & & & & \\
\hline URB & 0.4953 & 0.7291 & 0.2352 & 1 & & & & & & \\
\hline UNEM & -0.0291 & 0.0189 & -0.1352 & -0.0046 & 1 & & & & & \\
\hline MOB & 0.3489 & 0.6059 & 0.2653 & 0.4893 & 0.0097 & 1 & & & & \\
\hline INTER & 0.6589 & 0.6549 & 0.2886 & 0.5838 & -0.0432 & 0.5639 & 1 & & & \\
\hline PS & 0.4315 & 0.6427 & 0.1608 & 0.4232 & 0.0173 & 0.4485 & 0.5585 & 1 & & \\
\hline RQ & 0.5747 & 0.6723 & 0.2799 & 0.5968 & 0.0307 & 0.5316 & 0.6438 & 0.7273 & 1 & \\
\hline RL & 0.6174 & 0.6774 & 0.2655 & 0.5546 & -0.0091 & 0.4843 & 0.6728 & 0.7387 & 0.9131 & 1 \\
\hline
\end{tabular}

Table 6 presents estimation results which enables us to infer the influence of institutional characteristics on financial inclusion. As per the Hausman specification test, Fixed Effects is the most appropriate model. Hence we reject the null hypothesis. Based on a panel data across 120 countries, what do the estimation results reveal? The results show that the rule of law matters. Account ownership is higher in countries which upholds the rule of law. This confirms that in countries where rule of law is weak financial constraints are more widespread (Love, 2003). It further gives credence to our hypothesis that depositors have confidence in entrusting their savings to financial institutions when contracts between creditors and debtors are honoured. This finding is consistent with Ahokpossi et al. (2013).

The hypothesis that improved regulatory quality may lower financial intermediation costs and enhance financial inclusion is not supported here. Similarly, political stability is not significant in predicting financial inclusion. Thus, the conjecture that higher values of political stability impacts positively on financial inclusion is also not supported by the study findings.

Turning to control variables the positive and statistically significant income coefficient suggests that higher per capita incomes may enhance financial inclusion which is consistent with Gebrehiwot and Makina (2019) and Demirgüç-Kunt et al. (2017). Estimation results also reveals that people staying in urban regions have higher account(s) ownership compared to those residing in rural areas. Generally, there are more establishments of financial institutions in urban centres relative to rural areas, which lends credence to Kumar (2013).

On financial innovations, the estimated models predict that mobile phone subscriptions positively and significantly influences account penetration which is consistent with Amoah et al. (2020). This suggests that the possibility of having a mobile account is contingent on ownership of a deposit account. The coefficient estimates therefore provides evidence of the secondary effects of mobile money on deposit accounts. This also points to the important role that FinTech plays on mobile money and account penetration. We also find a significant and positive relationship between internet utilization rates and variations in account penetration. 
Contrary to Devlin (2005), our hypothesis that countries with higher unemployment levels are more likely to be financially excluded is not established. A potential explanation for the insignificant coefficient lies on the use of formal/wage-income data which shows negligible variations during the study period. It may as well be the case that most people in SSA are employed in informal sector but unlike in the developed economies, data may not be forthcoming. Further research is however necessary to corroborate this conjecture.

\section{Interaction Effects}

The estimated results reported in Table 6 are based on the premise that all institutional indicators affect account penetration across the regions equally. In Table 4 and consistent with the stylized facts section, we observed that account penetration and institutional quality indicators are lower in SSA relative to other regions. Suppose we assume that institutional quality might have a different effect on financial inclusion in SSA relative to the other regions. We can test this conditional hypothesis with an interaction term which is ideally an adjustment to the slope on each of the institutional variable for SSA.

Using an interaction model for example implies that there is one effect of rule of law on account penetration when SSA dummy $=0$, and a different effect when SSA dummy $=1$. Thus the effect of a unit increase in the rule of law on account penetration when SSA dummy $=0$ is given by the coefficient of rule of law. The overall effect of a unit increase in rule of law on the account penetration when SSA dummy=1 is given by the coefficient of rule of law plus the coefficient of the interaction term. On the contrary, if the effects are not different, then the interaction coefficient would be zero. This implies that we revert to the baseline regression without the interaction term.

Based on the estimation results, the interaction term coefficient for the rule of law is positive and statistically significant, implying that an extra unit on enforcement of rule of law translates to higher account penetration in SSA economies than the rest of the World. This is consistent with Anayiotos and Toroyan (2009) who concludes that financial sector across SSA economies operate within weak institutional environments. Interestingly, the regulatory quality coefficient which is not significant for the baseline regression turns out to be statistically significant when interacted with SSA dummy. This suggests that the impact is positive and significant for SSA economies. Financial institutions and depositors in SSA may therefore be operating in an environment characterized by excessive or challenging regulations, where rules are not efficiency enhancing. Thus, financial intermediation may be curtailed by lack of depositors' confidence. Indeed, Andrianova et al., (2015) shows that many SSA countries impose severe restrictions on bank activity with implications on efficiency and economies of scope.

Table 6. The impact of institutions on financial inclusion (including interaction effects)

\begin{tabular}{|c|c|c|c|c|c|c|c|}
\hline \multirow[t]{2}{*}{ Variable } & \multicolumn{7}{|c|}{ Variant model specifications } \\
\hline & Notation & 1 & 2 & 3 & 4 & 5 & 6 \\
\hline Intercept & & $\begin{array}{l}-2.7420 * * * \\
(-7.02)\end{array}$ & $\begin{array}{l}-2.9461 * * * \\
(-6.99)\end{array}$ & $\begin{array}{l}-2.6361 * * * \\
(-6.91)\end{array}$ & $\begin{array}{l}-2.5244 * * * \\
(-6.53)\end{array}$ & $\begin{array}{l}-2.4661 * * * \\
(-6.39)\end{array}$ & $\begin{array}{l}-2.4105^{* * * *} \\
(-6.37)\end{array}$ \\
\hline Log GDP per capita & GDP & $\begin{array}{l}0.2937 * * * \\
(5.61)\end{array}$ & $\begin{array}{l}0.3144^{* * * *} \\
(5.71)\end{array}$ & $\begin{array}{l}0.2622 * * * \\
(5.33)\end{array}$ & $\begin{array}{l}0.2371 * * * \\
(4.81)\end{array}$ & $\begin{array}{l}0.2472^{* * *} \\
(5.16)\end{array}$ & $\begin{array}{l}0.2346^{* * *} \\
(4.88)\end{array}$ \\
\hline Urban population & URB & $\begin{array}{l}0.0169 * * * \\
(3.94)\end{array}$ & $\begin{array}{l}0.0151^{* * * *} \\
(3.66)\end{array}$ & $\begin{array}{l}0.0174 * * * \\
(4.47)\end{array}$ & $\begin{array}{l}0.0181^{* * *} \\
(4.85)\end{array}$ & $\begin{array}{l}0.0169^{* * *} \\
(4.51)\end{array}$ & $\begin{array}{l}0.0174 * * * \\
(4.66)\end{array}$ \\
\hline Unemployment & UNEM & $\begin{array}{l}0.0049 \\
(1.33)\end{array}$ & $\begin{array}{l}0.0046 \\
(1.20)\end{array}$ & $\begin{array}{l}0.0047 \\
(1.31)\end{array}$ & $\begin{array}{l}0.0047 \\
(1.10)\end{array}$ & $\begin{array}{l}0.0049 \\
(1.41)\end{array}$ & $\begin{array}{l}0.0056 \\
(1.63)\end{array}$ \\
\hline $\begin{array}{l}\text { Mobile cellular } \\
\text { subscriptions }\end{array}$ & MOB & $\begin{array}{l}0.0010 * * * \\
(3.24)\end{array}$ & $\begin{array}{c}0.0010^{* * * *} \\
(3.19)\end{array}$ & $\begin{array}{l}0.0010 * * * \\
(3.38)\end{array}$ & $\begin{array}{c}0.0009 * * * \\
(3.66)\end{array}$ & $\begin{array}{l}0.0010^{* * * *} \\
(3.48)\end{array}$ & $\begin{array}{l}0.0010 * * * \\
(3.61)\end{array}$ \\
\hline Fixed broadband & INTER & $\begin{array}{l}0.0071 * * * \\
(3.92)\end{array}$ & $\begin{array}{l}0.0069^{* * * *} \\
(3.84)\end{array}$ & $\begin{array}{l}0.0073 * * * \\
(4.10)\end{array}$ & $\begin{array}{l}0.0069 * * * \\
(3.81)\end{array}$ & $\begin{array}{l}0.0073 \\
(4.11)\end{array}$ & $\begin{array}{l}0.0069 * * * \\
(3.67)\end{array}$ \\
\hline Political Stability & PS & $\begin{array}{l}-0.0151 \\
(-1.01)\end{array}$ & $\begin{array}{l}-0.0349 \\
(-1.32)\end{array}$ & & & & \\
\hline $\begin{array}{l}\text { Political } \\
\text { StabilityXSSA }\end{array}$ & PSXSSA & & $\begin{array}{l}0.0337 \\
(1.04)\end{array}$ & & & & \\
\hline Regulatory Quality & RQ & & & $\begin{array}{l}0.0266 \\
(0.44)\end{array}$ & $\begin{array}{l}0.0910 \\
(1.58)\end{array}$ & & \\
\hline $\begin{array}{l}\text { Regulatory } \\
\text { QualityXSSA }\end{array}$ & RQXSSA & & & & $\begin{array}{l}0.1841^{* * * *} \\
(2.72)\end{array}$ & & \\
\hline Rule of Law & RL & & & & & $\begin{array}{c}0.0874 * * \\
(2.11)\end{array}$ & $\begin{array}{l}0.1490 * * * \\
(3.34)\end{array}$ \\
\hline
\end{tabular}




\begin{tabular}{|c|c|c|c|c|c|c|}
\hline Rule of lawXSSA & RLXSSA & & & & & $\begin{array}{l}0.1689 \text { *** } \\
(4.60)\end{array}$ \\
\hline $\mathrm{R}^{2}$ & 0.4891 & 0.4821 & 0.4787 & 0.4879 & 0.4837 & 0.4917 \\
\hline Observations & 1490 & 1490 & 1490 & 1490 & 1490 & 1490 \\
\hline Hausman & \multicolumn{6}{|l|}{$\operatorname{chi} 2(7)=24.03$} \\
\hline specification test & \multicolumn{6}{|l|}{ Prob $>$ chi $2=0.0000$} \\
\hline & \multicolumn{6}{|c|}{ Ho: difference in coefficients not systematic } \\
\hline
\end{tabular}

Note. This Table presents Fixed Effects regression results conducted to determine the influence of institutional variables on financial inclusion. T-Statistics are in parentheses. Significance at the $10 \%, 5 \%$, and $1 \%$ level is denoted by $*, * *$ and $* * *$ respectively.

\section{Conclusion}

Although the frontier of knowledge in financial inclusion seeks to provide answers as to why some economies are financially more inclusive than others, empirical evidence on the role of institutions remains relatively thin. Using cross country data covering 120 countries for the period 2004 to 2019, this study sought to understand the role played by institutional quality on the ownership of deposit accounts. In addition, the policies that are especially effective in fostering financial inclusion. For this purpose, a fixed effects model along with a financial inclusion proxy and three measures of institutional quality were estimated. This paper established that inclusive finance is non-negligibly influenced by the institutional context.

We uncover new evidence that inclusive finance is positively influenced by the rule of law and quality of regulations. However, the direction and magnitude of the impact is sensitive to regions. The impact of an extra unit of regulation reforms and rule of law on account penetration matters for SSA economies than the rest of the World. Upholding the rule of law implies that greater consumer protection may be positively related to ownership of bank accounts. Well-developed legal systems, strong law enforcement and efficiency enhancing regulations may actually make it less costly for financial inclusion to be realized in SSA. Quality regulations on banking activities may lower the cost of financial intermediation. Most SSA economies however face challenges in this regard. On measures of institutional quality, very few are ranked above global averages (Miller et al., 2021).

By taking institutional characteristics into account, the analysis reported in this paper provides interesting insights for policy reforms particularly in Sub Sahara Africa. Efforts should be targeted at improving the institutions relevant to the realization of inclusive finance. This may ultimately create conducive climate for financial inclusion. This study could be extended at the country level so as to provide country-level policy implications.

\section{Acknowledgments}

This paper was supported by African Economic Research Consortium (AERC) under the thematic research grant number RT19523, to the author. All errors and omissions are the author's sole responsibilities.

\section{References}

Aaberge, R., Liu, K., \& Yu, Y. (2017). Political Uncertainty and Household Savings. Journal of Comparative Economics, 45(1), 154-170. https://doi.org/10.1016/j.jce.2015.12.011

Acemoglu, D., \& Johnson, S. (2005). Unbundling Institutions. Journal of Political Economy, 113, 949-95. https://doi.org/10.1086/432166

Acemoglu, D., \& Robinson, J. A. (2008). Persistence of Power, Elites, and Institutions. American Economic Review, 98(1), 267-293. https://doi.org/10.1257/aer.98.1.267

Ahamed, M., \& Mallick, S. (2019). Is Financial Inclusion Good for Bank Stability? International Evidence. Journal of Economic Behaviour \& Organization, 157, 403-427. https://doi.org/10.1016/j.jebo.2017.07.027

Ahokpossi, C., Ismail, K., Karmakar, S., \& Koulet-Vickot, M. (2013). Financial Depth in the WAEMU: Benchmarking against Frontier SSA Countries. IMF Working Paper WP/13/161. https://doi.org/10.5089/9781484309391.001

Alence, R. (2004). Political Institutions and Developmental Governance in Sub-Saharan Africa. The Journal of Modern African Studies, 42(2),163-187. https://doi.org/10.1017/S0022278X04000084

Allen, F., Demirguc-Kunt, A., Klapper, L., \& Peria, M.S. (2016). The Foundations of Financial Inclusion: Understanding Ownership and Use of Formal Accounts. Journal of Financial Intermediation, 27, 1-30. https://doi.org/10.1016/j.jfi.2015.12.003 
Alter, A., \& Yontcheva, B. (2015). Financial Inclusion and Development in the CEMAC. IMF Working Paper WP/15/235. https://doi.org/10.5089/9781484317556.001

Amidžić, G., Massara, A., \& Mialou, A. (2014). Assessing Countries' Financial Inclusion Standing-A New Composite Index. IMF Working Paper No. 14/36. https://doi.org/10.5089/9781475569681.001

Amoah, A., Korle, K., \& Asiama, R. K. (2020). Mobile Money as a Financial Inclusion Instrument: What are the Determinants? International Journal of Social Economics, 47(10), 1283-1297. https://doi.org/10.1108/IJSE-05-2020-0271

Anarfo, E. B., Abor, J., Osei, K., \& Gyeke-Dako, A. (2019). Financial Inclusion and Financial Sector Development in Sub-Saharan Africa: A Panel VAR Approach. International Journal of Managerial Finance, 15(4), 444-463. https://doi.org/10.1108/JJMF-07-2018-0205

Anayiotos, G., \& Toroyan, H. (2009). Institutional Factors and Financial Sector Development: Evidence from Sub-Saharan Africa. IMF Working Paper No. 09/258. https://doi.org/10.5089/9781451874044.001

Andrianova, S., Baltagi, H., Demetriades, P \& Fielding, D. (2015). Why Do African Banks Lend So Little? Oxford Bulletin of Economics and Statistics 77(3), 339-359. https://doi.org/10.1111/obes.12067

Anginer D, Demirgüç-Kunt, A., \& Mare, D. S. (2018). Bank Capital, Institutional Environment and Systemic Stability. Journal of Financial Stability, 37, 97-106. https://doi.org/10.1016/j.jfs.2018.06.001

Aron, J. (2018). Mobile Money and the Economy: A Review of the Evidence. The World Bank Research Observer, 33(2), 135-188. https://doi.org/10.1093/wbro/lky001

Aterido, R., Beck, T., \& Iacovone, L. (2013). Access To Finance In Sub-Saharan Africa: Is There a Gender Gap? World Development, 47, 102-120. https://doi.org/10.1016/j.worlddev.2013.02.013

Baltagi, H. (2021). Econometric analysis of panel data (6th ed.). John Wiley \& Sons. https://doi.org/10.1007/978-3-030-53953-5

Beck, T., \& Levine, R. (2008). Legal Institutions and Financial Development. World Bank Policy Research Working Paper No. 3136, Washington DC. World Bank. https://doi.org/10.1596/1813-9450-3136

Beck, T., Demirgüç-Kunt, A., \& Maksimovic, V. (2003). Bank Competition, Financing Obstacles and Inclusion to Credit. World Bank Policy Research Paper No. 2996. Washington, DC: World Bank. https://doi.org/10.1596/1813-9450-2996

Beck, T., Levine, R., \& Levkov, A. (2010). Big Bad Banks? The Winners and Losers from Bank Deregulation in the United States. Journal of Finance, 65(5), 1637-1667. https://doi.org/10.1111/j.1540-6261.2010.01589.x

Beck, T., Senbet, L., \& Simbanegavi, W. (2015). Financial Inclusion and Innovation in Africa: An Overview. Journal of African Economies, 24, 3-11. https://doi.org/10.1093/jae/eju031

BFA. (2009). How Enabling is the Latin American Environment for Mobile Money? Briefing Note 1, Somerville, MA: Bankable Frontier Associates.

Cámara, N., \& Tuesta, D. (2015). Factors That Matter for Financial Inclusion: Evidence from Peru. The IEB International Journal of Finance, 10, 10-31. https://doi.org/10.5605/IEB.10.1

Chauvet, L., \& Jacolin, L. (2017). Financial Inclusion, Bank Concentration, and Firm Performance. World Development, 97, 1-13. https://doi.org/10.1016/j.worlddev.2017.03.018

Chen, L., Li, H., Liu, F. H., \& Zhou, Y. (2020). Bank Regulation and Systemic Risk: Cross Country Evidence. Review of Quantitative Finance and Accounting. https://doi.org/10.1007/s11156-020-00947-0

Dar, A. B., \& Ahmed, F. (2020). Financial Inclusion Determinants and Impediments in India: Insights from the Global Financial Inclusion Index. Journal of Financial Economic Policy, 1757-6385. https://doi.org/10.1108/JFEP-11-2019-0227

Demetriades, P., \& Fielding, D. (2012). Information, Institutions, and Banking Sector Development in West Africa. Economic Inquiry, 50, 739-753. https://doi.org/10.1111/j.1465-7295.2011.00376.x

Demir, A., Pesqué-Cela, V., Altunbas, Y., \& Murinde, V. (2020). Fintech, Financial Inclusion and Income Inequality: A Quantile Regression Approach. The European Journal of Finance. https://doi.org/10.1080/1351847X.2020.1772335

Demirgüç-Kunt, A., Klapper, L., Singer, D., \& Oudheusden, P. (2015). The Global Findex Database 2014: Measuring Financial Inclusion around the World. Policy Research Working Paper 7255, World Bank, 
Washington, DC. https://doi.org/10.1596/1813-9450-7255

Demirgüç-Kunt, A., Leora, K., \& Dorothe, S. (2017). Financial Inclusion and Inclusive Growth. A Review of Recent Empirical Evidence. Policy Research Working Paper; no. WPS 8040. Washington DC. World Bank. https://doi.org/10.1596/1813-9450-8205

Devlin, J. F. (2005). A Detailed Study of Financial Exclusion in the UK. Journal of Consumer Policy, 28, 75-108. https://doi.org/10.1007/s10603-004-7313-y

Dupas, P., \& Robinson, J. (2013). Savings Constraints and Microenterprise Development: Evidence from a Field Experiment in Kenya. American Economic Journal: Applied Economics, 5, 163-92. https://doi.org/10.1257/app.5.1.163

Eldomiaty, T., Hammam, R., \& Bakry, R. (2020). Institutional Determinants of Financial Inclusion: Evidence from World Economies. International Journal of Development Issues, 19(2), 217-228. https://doi.org/10.1108/IJDI-08-2019-0147

Emara, N., \& Said, A. (2021). Financial inclusion and economic growth: The role of governance in selected MENA countries. International Review of Economics \& Finance, 75, 34-54. https://doi.org/10.1016/j.iref.2021.03.014

Fergusson, L. (2006). Institutions For Financial Development: What Are They And Where Do They Come From? Journal of Economic Surveys, 20(1), 27-70. https://doi.org/10.1111/j.0950-0804.2006.00275.x

Gani, A., \& Ngassam, C. (2008). Effect of Institutional Factors on Stock Market Development in Asia. American Journal of Finance and Accounting, 1, 103-120. https://doi.org/10.1504/AJFA.2008.019947

Gebrehiwot, K. G., \& Makina, D. (2019). Macroeconomic Determinants of Financial Inclusion: Evidence Using Dynamic Panel Data Analysis. In Extending Financial Inclusion in Africa (pp. 167-191). Academic Press. https://doi.org/10.1016/B978-0-12-814164-9.00008-6

Girón, A., Kazemikhasragh, A., Cicchiello, A. F., \& Panetti, E. (2021). Financial Inclusion Measurement in the Least Developed Countries in Asia and Africa. Journal of the Knowledge Economy. https://doi.org/10.1007/s13132-021-00773-2

Grohmann, A., Klühs, T., \& Menkhoff, L. (2018). Does Financial Literacy Improve Financial Inclusion? Cross Country Evidence. World Development, 111, 84-96. https://doi.org/10.1016/j.worlddev.2018.06.020

Huang, Y. (2010). Political Institutions and Financial Development: An Empirical Study. World Development, 38, 1667-1677. https://doi.org/10.1016/j.worlddev.2010.04.001

International Monetary Fund. (2021). Financial Access Survey. Washington, DC: International Monetary Fund.

Johnson, S., \& Williams, R. (2016). The Political Economy of Financial Inclusion: Tailoring Donor Policy to Fit. Development Policy Review, 34(5), 721-743. https://doi.org/10.1111/dpr.12170

Kaufmann, D., Kraay, A., \& Mastruzzi, M. (2009). Governance Matters V: Governance Indicators for 1996-2008. Retrieved from http://info.worldbank.org/governance/wgi/resources.htm

Khan, I., Khan, I., Sayal, A. U., \& Khan, M. Z. (2021). Does Financial Inclusion Induce Poverty, Income Inequality, And Financial Stability: Empirical Evidence From The 54 African Countries? Journal of Economic Studies. https://doi.org/10.1108/JES-07-2020-0317

Khmous, D. F., \& Besim, M. (2020). Impact of Islamic Banking Share on Financial Inclusion: Evidence from MENA. International Journal of Islamic and Middle Eastern Finance and Management, 13(4), 655-673. https://doi.org/10.1108/IMEFM-07-2019-0279

Kling, G., Pesqué-Cela, V., Tian, L., \& Luo, D. (2020). A Theory of Financial Inclusion and Income Inequality. The European Journal of Finance. https://doi.org/10.1080/1351847X.2020.1792960

Kumar, N. (2013). Financial Inclusion and Its Determinants: Evidence from India. Journal of Financial Economic Policy, 5, 4-19. https://doi.org/10.1108/17576381311317754

Liu, J., \& Zhong, R. (2017). Political Uncertainty and a Firm's Credit Risk: Evidence from the International CDS Market. Journal of Financial Stability, 30, 53-66. https://doi.org/10.1016/j.jfs.2017.03.006

Love, I. (2003). Financial Development and Financing Constraints: International Evidence from the Structural Investment Model. Review of Financial Studies, 16(3), 765-791. https://doi.org/10.1596/1813-9450-2694

Lu, W., Niu, G., \& Zhou, Y. (2021). Individualism and financial inclusion. Journal of Economic Behaviour \& 
Organization, 183, 268-288. https://doi.org/10.1016/j.jebo.2021.01.008.

Martinez, L. B., Scherger, V., Guercio, M., \& Orazi, S. (2020). Evolution of Financial Inclusion in Latin America: Management Area: Business Economics. Academia Revista Latinoamericana de Administracion, 33(2), 261-276. https://doi.org/10.1108/ARLA-12-2018-0287

Mas, I., \& Radcliffe, D. (2011). Mobile Payments Go Viral: M-PESA in Kenya. Journal of Financial Transformation, 32, 169-182.

Mhlanga, D., Dunga, S., \& Moloi, T. (2020). Financial Inclusion and Poverty Alleviation among Smallholder Farmers in Zimbabwe. Eurasian Journal of Economics and Finance, 8(3), 168-182. https://doi.org/10.15604/ejef.2020.08.03.004

Miller, T., Kim, A. B., Roberts, J. M., \& Tyrrell, P. (2021). 2021 Index of Economic Freedom. The Heritage Foundation: Washington, D.C.

Minhaj, A., Imran, N., Shujahat, H., \& Wajeeh, U. (2020). Financial Inclusion, Institutional Quality and Financial Development: Empirical Evidence from OIC Countries. The Singapore Economic Review. https://doi.org/10.1142/S0217590820420084

Mohammed, J. I., Mensah, L., \& Gyeke-Dako, A. (2017). Financial Inclusion and Poverty Reduction in Sub-Saharan Africa. African Finance Journal, 19(1), 1-22. 10.1080/23311886.2021.1903138

Mostak, A. M., Ho, S. J., Mallick, S. K., \& Matousek, R. (2021). Inclusive Banking, Financial Regulation and Bank Performance: Cross-Country Evidence. Journal of Banking \& Finance, 124(C). https://doi.org/10.1016/j.jbankfin.2021.106055

Neaime, S., \& Gaysset, I. (2018). Financial Inclusion and Stability in MENA: Evidence from Poverty and Inequality. Finance Research Letters, 24, 230-237. https://doi.org/10.1016/j.frl.2017.09.007

Nguyen, T. T. H. (2021). Measuring Financial Inclusion: A Composite FI Index for the Developing Countries. Journal of Economics and Development, 23(1), 77-99. https://doi.org/10.1108/JED-03-2020-0027

Nizam, R., Karim, Z. A., Rahman, A. A., \& Sarmidi, T. (2020). Financial Inclusiveness and Economic Growth: New Evidence Using a Threshold Regression Analysis. Economic Research-Ekonomska Istraživanja, 33(1), 1465-1484. https://doi.org/10.1080/1331677X.2020.1748508

North, D. C. (1990). Institutions, Institutional Change and Economic Performance. Cambridge University Press, Cambridge. https://doi.org/10.1017/CBO9780511808678

Nsiah, A. Y., Yusif, H., Tweneboah, G., Agyei, K., \& Baidoo, S. T. (2021). The Effect Of Financial Inclusion On Poverty Reduction In Sub-Sahara Africa: Does Threshold Matter? Cogent Social Sciences, 7(1), 1903138. DOI: $10.1080 / 23311886.2021 .1903138$

Ofori-Abebrese, G., Baidoo, S. T., \& Essiam, E. (2020). Estimating the Effects of Financial Inclusion on Welfare in Sub-Saharan Africa. Cogent Business \& Management, $7(1)$. https://doi.org/10.1080/23311975.2020.1839164

Onyinye I., Orji, A., Ogbuabor, J \& Nwosu, E. (2019). Do Financial Stability And Institutional Quality Have Impact On Financial Inclusion In Developing Economies? A new evidence from Nigeria. International Journal of Sustainable Economy, 11(1), 18-40. https://doi.org/10.1504/IJSE.2019.096541

Ouma, S., Odongo, T., \& Were, W. (2017). Mobile Financial Services And Financial Inclusion: Is It A Boon For Savings Mobilization? Review of Development Finance, 7, 29-35. https://doi.org/10.1016/j.rdf.2017.01.001

Özlem, S., Doğan, M., \& Soud, N. (2018). Financial Development and Governance Relationships. Applied Economics Letters, 25(20), 1466-1470. https://doi.org/10.1080/13504851.2018.1430311

Panos, G. A., \& Wilson, J. (2020). Financial Literacy and Responsible Finance in the Fintech Era: Capabilities and Challenges. The European Journal of Finance, 26, 4-5, 297-301. https://doi.org/10.1080/1351847X.2020.1717569

Patnam, M., \& Yao, W. (2020). The Real Effects of Mobile Money: Evidence from a Large-Scale Fintech Expansion. IMF Working Paper No. 20/138. https://doi.org/10.5089/9781513550244.001

Prymostka, L. O., Krasnova, I., Prymostka, O., Nikitin, A., \& Shevaldina, V. (2020). Financial Inclusion in Ukraine: Determinants and Evaluation. Financial and Credit Activity: Problems of Theory and Practice, 2(33), 500-512. https://doi.org/10.18371/fcaptp.v2i33.207218

Roe, M., \& Siegel, J. (2011). Political Instability: Effects on Financial Development, Roots in the Severity of 
Economic Inequality. Journal of Comparative Economics, 39(3), 279-309. https://doi.org/10.1016/j.jce.2011.02.001

Salignac, F., Muir, K., \& Wong, J. (2016). Are You Really Financially Excluded If You Choose Not To Be Included? Insights from Social Exclusion, Resilience and Ecological Systems. Journal of Social Policy, 45(02), 269-286. https://doi.org/10.1017/S0047279415000677

Sarma, M. (2008). Index of Financial Inclusion. Indian Council For Research On International Economic Relations. Working Paper No. 215.

Saydaliyev, H. B., Chin, L., \& Oskenbayev, Y. (2020). The Nexus of Remittances, Institutional Quality, and Financial Inclusion. Economic Research-Ekonomska Istraživanja, 33(1), 3528-3544. https://doi.org/10.1080/1331677X.2020.1774795

Vaid, Y, K., Vikram, S., \& Monika, S. (2020). Determinants of Successful Financial Inclusion in Low-Income Rural Population. The Indian Economic Journal, 68(1), 82-100. https://doi.org/10.1177/0019466220962057

Wale, L. E., \& Makina, D. (2017). Account Ownership and Use of Financial Services among Individuals: Evidence from Selected Sub-Saharan African Economies. African Journal of Economic and Management Studies, 8(1), 19-35. https://doi.org/10.1108/AJEMS-03-2017-146

Wang, X., \& Guan, J. (2017). Financial Inclusion: Measurement, Spatial Effects and Influencing Factors. Applied Economics, 49(18), 1751-1762. https://doi.org/10.1080/00036846.2016.1226488

William, J., \& Suri, T. (2014). Risk Sharing and Transaction Costs: Evidence from Kenya's Mobile Money Revolution. American Economic Review, 104, 183-223. https://doi.org/10.1257/aer.104.1.183

World Bank. (2016). Payment Systems Survey 2015: Universal Financial Access Survey. World Bank, Washington, DC.

Zinsa, A., \& Weill, L. (2016). The Determinants of Financial Inclusion in Africa. Review of Development Finance, 6, 46-57. https://doi.org/10.1016/j.rdf.2016.05.001

Zulkhibri, M., \& Ghazal, R. (2017). The Impacts of Governance and Institution on Financial Inclusion: Evidence from Muslim Countries and Developing Economies. JKAU: Islamic Econ., 30, 37-60. https://doi.org/10.4197/Islec.30-SI.3

\section{Copyrights}

Copyright for this article is retained by the author(s), with first publication rights granted to the journal.

This is an open-access article distributed under the terms and conditions of the Creative Commons Attribution license (http://creativecommons.org/licenses/by/4.0/). 